\title{
The influence of financial ratios on non performing financing of the sharia rural banks of Special Region of Yogyakarta (BPRS DIY) period 2015 - 2018
}

\author{
Taufikur Rahman*, Khusna Fatmawati \\ Department of Accounting, Faculty of Economics and Business, Universitas \\ Gadjah Mada, Yogyakarta, Indonesia \\ *Corresponding author: taufikur@ugm.ac.id
}

Article History

Received, 6 April 2020

Revised 1, 28 April 2020

Revised 2, 3 May 2020

Accepted, 20 May 2020

\begin{abstract}
Purpose: This study aims to analyze the effect of financial performance on Non-Performing Financing of Sharia Rural Banks (BPRS) in the Special Region of Yogyakarta (DIY). This study provides an empirical contribution as research that adds evidence in the financial sector, especially banking risks related to the determinants of Non-Performing Financing of Sharia rural banks in DIY in 2015-2018.
\end{abstract}

Methodology: Research data were obtained from quarterly financial reports at the Financial Services Authority for the period 2015 to 2018 with a research sample of 9 BPRS.

Findings: The results of the findings show that return on assets (ROA) and operating income operating expenses (BOPO) which have a significant effect on non-performing financing. Meanwhile, return on equity, financing to deposit ratio, and capital adequacy ratio does not have a significant effect on the nonperforming financing of BPRS in DIY.

Originality/Value: To the author's knowledge, as the variations of the results among researchers exist, the findings of this research provides deeper insight into the literature of Non Performing Financing Bank regarding its financial ratio.

Keywords: Non performing financing, shariah rural bank, financial ratios

Cite this:

Rahman, T. \& Fatmawati, K. (2020). The influence of financial ratios on non performing financing of the sharia rural banks of Special Region of Yogyakarta (BPRS DIY) period 2015 - 2018. Asian Journal of Islamic Management, 2(1), 25-35. DOI: 10.1108/AJIM.vol2.iss1.art3

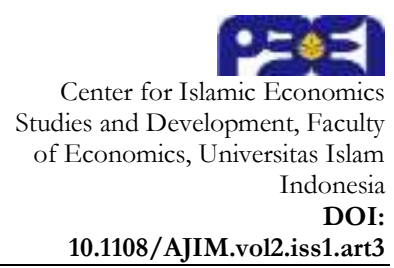

\section{Introduction}

The development of micro businesses in Indonesia is a driving force for people's economic growth. The majority of micro-businesses in Indonesia are carried out by entrepreneurs with a small rupiah value compared to large businesses owned by only a handful of conglomerates. The number of micro and small enterprises (MSEs) in Indonesia in 2017 was 26,073,689 (BPS, 2019) which shows that many people depend on this business for their lives.

Micro and small businesses need capital as well as large businesses. Micro-small business capital for some people is not an easy thing because it is not uncommon after the business is established, its operational activities are not running. In the 2015-2018 period, at least 1.7 million 
MSMEs went bankrupt because they could not compete in this industrial era (Mentari.news, 2019). The bankruptcy that they experienced made them rack their brains to get their capital back and start their new business. The existence of several other business constraints also affected the establishment of micro businesses, but capital constraints are a major obstacle experienced at least by $60.14 \%$ of micro and small entrepreneurs in Indonesia (BPS, 2019).

MSEs financing sources can be obtained both internally through their own capital and externally through formal and informal institutions. Formal institutions are divided into banking institutions and non-banking institutions. As many as 11.70\% of MSEs received financing from financial institutions (BPS, 2019). Unfortunately, formal financial institutions such as banks have technical access which tends to be complicated, thus hampering the obtaining of the financing (Bank Indonesia, 2017). Therefore, the Microfinance Institution (MFI) emerged, or in other words it is called the Microfinance Institution (LKM).

Micro Finance Institutions are supervised by the Financial Services Authority (OJK) and regulated in Law Number 1 Year 2013 which plays a role in providing business development and community empowerment services (OJK, 2017). Over time, products from MFIs such as insurance, savings, or financing products have grown. One that is included in the LKM is the Rural Bank (BPR).

The existing LKMs raise their own concerns for Muslim communities where they do not want to make loans with an element of usury. This is in accordance with Islamic law that usury is something that is forbidden in religion. These concerns led to the establishment of Sharia Microfinance Institutions (LKMS), namely LKMs based on Islamic law. The factors that determine the existence of LKMS are sharia principles, Islamic moral values, complementing the existence of micro-business financial services, and the dominant micro-small business group.

One of the LKMS which has an established position is the Sharia Rural Bank (BPRS). BPRS in Indonesia is regulated in the Financial Services Authority Regulation Number 3/POJK.03/2016. Referring to Law No. 21 year 2008, BPRS is defined as a financial institution in the form of a bank in which business activities are carried out based on sharia principles but do not provide services in payment traffic. Although classified as well-established, BPRS has a high enough risk in dealing with financing problems so that risk management is an important matter. Kumar et al. (2018) describe that an effective financial and banking system is identified as the ability to adjust the effectiveness of saving and investment to encourage growth and development.

The increase in financing has an impact on increasing the risk of collectability over the financing so that financing is often classified as substandard, doubtful, even to non-performing. This problematic financing is known as Non Performing Financing (NPF) in Islamic banking. Meanwhile, conventional banking is called a Non Performing Loan (NPL).

Research by Rahman et al. (2017) stated that their findings can help commercial banks to maintain standard financial ratios in order to improve the quality of their loans and will be useful for examining policies on existing banking supervision.

Research related to the determinants of conventional banking non-performing loans (NPLs) has been widely conducted (Dimitrios et al., 2016; Rahman et al., 2017; Kumar et al., 2018; Koju et al., 2018) while research on non-performing financing (NPF) determinants in Islamic banking financing has not been widely discussed (Alandejani and Asutay, 2017; Indrajaya, 2019; Al Wesabi and Ahmad, 2013). Referring to the various results of these studies, the determinants of banking Non-Performing Loans indicate different determinants of each study.

In 2018, total financing in the Special Region of Yogyakarta reached IDR 499,112 million, and had an NPF of $6.95 \%$. This NPF is classified as lower than the NPF in Indonesia which reaches $9.30 \%$. The greater the NPF value, the worse the bank's health is. Therefore, this study becomes relevant to understand the factors that influence the NPF of BPRS in the Special Region of Yogyakarta (DIY). 


\section{Literature Review and Hypotheses Development}

\section{Main Function of the Bank}

Banks have the main function of being a financial intermediary, namely collecting public funds in the form of deposits, channeling funds to the public in the form of credit, and launching trade transactions and money circulation so that they are referred to as Financial Intermediary Institutions (Kuncoro and Suhardjono, 2012).

1) Functions of raising funds

Credit can be given to the public when the bank has funds. The product instruments used by banks to collect public funds include demand deposit, deposits and savings.

2) Function of channeling funds

After the collection is conducted, the bank should place the funds in the form of placements that provide the most benefits, one of them is in the form of credit. Unfortunately, the placement has a big risk as well.

3) Functions to facilitate trade payments and money circulation

This last function can run because of various services provided by the bank. These various services can be grouped based on the parties involved, namely clients and banks or only clients.

\section{Financing Risk}

According to the OJK, financing is a funding support with a mechanism that generally involves several parties in meeting the needs or procurement of certain goods/assets/services (sikapiuangmu.ojk.go.id). These various parties include the funder, the goods/asset/service provider, and the party who uses certain goods/assets/services. There are two classifications of financing according to the nature of their use (Antonio, 2001), among others

1. Productive financing is financing intended to meet production needs such as business development.

2. Consumptive financing is financing intended to meet the consumption needs of consumable goods.

The financing provided by BPRS from year to year has increased which is directly proportional to the increase in the number of MSMEs in Indonesia as shown in Figure 1. An increase in financing will affect Non-Performing Financing (NPF) in sharia banking or NonPerforming Loans (NPL) in conventional banking.

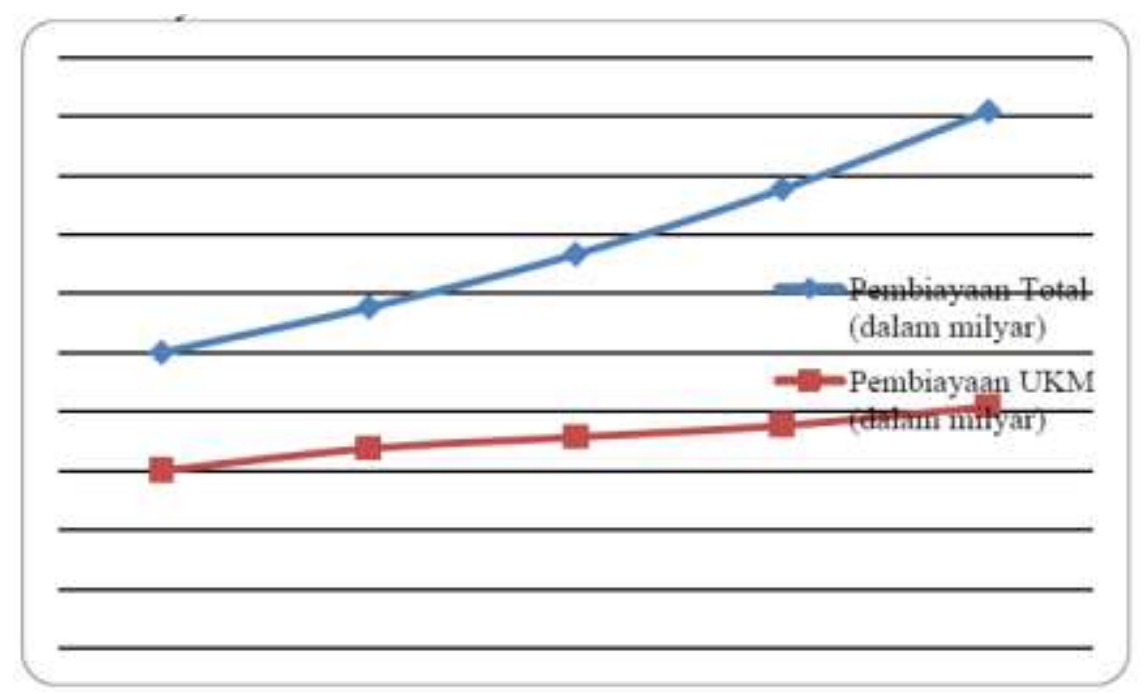

Figure 1. BPRS Financing in Indonesia 2014-2018

Source: Processed from Sharia Banking Statistics Desember 2018 - January 2020 
Figure 2 shows an increase in NPF from year to year and then decreases in 2018. This increase indicates a fairly high financing risk for BPRS. A low level of NPL indicates a healthy financial system, while a high NPL indicates the vulnerability of bank health (Koju et al., 2018). The higher NPF percentage can encourage the amount of financing that falls into the noncurrent category, namely substandard, doubtful, and non-performing.

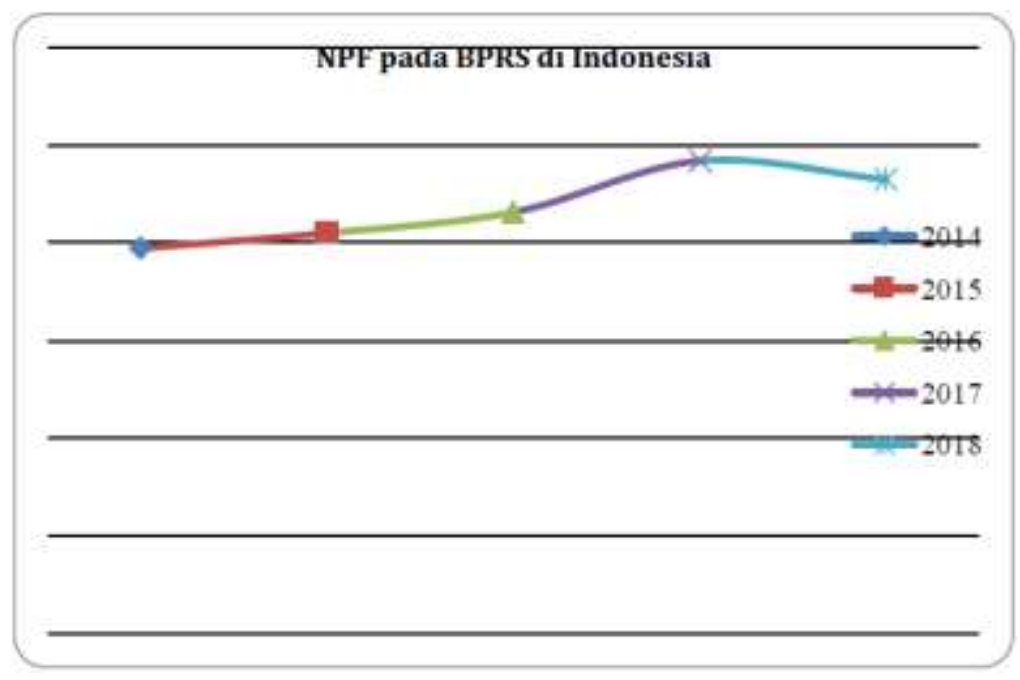

Figure 2. NPF Gross BPRS in Indonesia 2014-2018

Source: (OJK, 2018)

Based on OJK Regulation Number 15/POJK.03/2017 Article 3 (2), when the ratio of bad credit or the net non-performing financing ratio is above $5 \%$ of the total credit or financing provided, it can be a sign that the bank has potential difficulties that endanger the sustainability of the company. However, the limit for the NPF ratio at BPRS is different according to the Draft OJK Circular Number /POJK.03/2019 which is no more than 7\%.

\section{The relationship between ROA and NPF}

ROA is proxied as a performance that shows the profitability of the bank (Godlewski, 2004) on its assets. A bigger ROA indicates good financial performance and a stable financial system (Koju et al., 2018). Research by Rahman et al. (2017), Ekanayake et al. (2015), and Dimitrios et al. (2016) found that there was a negative influence between FDR and NPL. However, the study of Koju et al. (2018) resulted in a positive relationship. Therefore, the hypothesis can be developed into

H1: ROA has a negative effect on NPF

\section{Relationship between ROE and NPF}

ROE measures the profitability of a bank based on its capital. Bank performance, which is proxied by ROE, can be considered as a key indicator of bad credit in the future (Abid et al., 2014). Various studies have the final results that describe a negative relationship between ROE and NPL (Kumar et al., 2018; Dimitrios et al., 2016; Abid et al., 2014). Therefore, the hypothesis is then developed to become

H2: ROE has a negative effect on NPF

\section{The relationship between FDR and NPF}

The financing to funding ratio is another term for the Credit to Deposit Ratio (CDR) or the Loan to Deposit Ratio (LDR) found in sharia banks. CDR is influenced by the operational strategy of bank management (Rahman et al., 2017). Credit considerations are one of the important 
considerations that cause loan problems (Jimeze and Saurian, 2006). The FDR/CDR variable has a positive relationship with NPL (Rahman et al., 2017; Indrajaya, 2019). However, the results of research by Koju et al. (2018) outlines a negative relationship between CDR and NPL. Based on these descriptions, the hypothesis can be developed into

H3: FDR has a positive effect on NPF

\section{The relationship between CAR and NPF}

The CAR aims to assess the extent of the BPRS's capital adequacy to cover losses and meet the specified KPMM requirements (OJK, 2019). The CAR variable has been extensively studied regarding its relationship to NPL. Kumar et al. (2018) proxies solvency (SOL) as a CAR which finds that SOL has a positive relationship with NPL. In contrast to other studies (Rahman et al., 2017; Koju et al., 2018; Indrajaya, 2019) which suggest that CAR and NPL have a negative relationship. Based on this explanation, the hypothesis can be developed into

H4: CAR has a negative effect on NPF

\section{The relationship between BOPO and NPF}

Operating Expenses Operating Income (BOPO) is another term for the Operational Efficiency Ratio (REO) or inefficiency. An increase in operating expenses will increase the increase in NPLs. Koju et al. (2017) outlining the positive influence of BOPO on NPL shows that poor management in the banking system can cause banking crises. The BOPO variable has a positive relationship with NPL (Koju et al., 2017, Indrajaya, 2019; Abid et al, 2014). In contrast to Kumar et al. (2018) suggested a negative relationship between BOPO and NPL. Based on this explanation, the following hypothesis can be developed into

H5: BOPO has a positive effect on NPF

\section{Methods}

This research is included in quantitative research using secondary data obtained from publication reports on the Financial Services Authority website.

In this study, the dependent variable used is Non Performing Financing. Meanwhile, there are five independent variables used, namely ROA, ROE, FDR, CAR, and BOPO. The study population is the SRB in DIY. Meanwhile, the sample selection used a purposive sampling method with the following criteria: 1) Sharia Rural Banks registered with the OJK during the third quarter of 2015 to the fourth quarter of 2018, 2) Sharia Rural Banks that have published quarterly financial reports on the OJK from the third quarter of 2015 until the fourth quarter of 2018.

\section{Results}

\section{Regression Model Test}

\section{Lagrange multiplier test}

This test is conducted to choose which model is more suitable between pooled OLS and random effects. The null hypothesis (H0) of the LM test is that the pooled OLS model is more precise than the random effects model. If Prob $>\mathrm{F}$ is less than $\alpha$ then $\mathrm{H} 0$ is rejected.

Table 1. Lagrange Multiplier Test Results

\begin{tabular}{cccc}
\hline Variable & Prob $>$ F & $\alpha$ & Result \\
\hline NPF & 0.0000 & 0.05 & $($ Prob $>$ F $)<\alpha$ \\
\hline
\end{tabular}

Source: Processed secondary data, 2020 
Based on the LM test $(\operatorname{Prob}>\mathrm{F})<\alpha$ so that $\mathrm{H} 0$ is rejected, which means that the random effect model is more suitable.

\section{Chow test}

This test is conducted to determine which model is more appropriate between pooled OLS and fixed effects. The null hypothesis (H0) of the chow test is that the pooled OLS model is more precise than the fixed effects model. If Prob $>$ Chibar2 is smaller than $\alpha$ then $\mathrm{H} 0$ is rejected.

Table 2. Chow Test Results

\begin{tabular}{cccc}
\hline Variable & Prob $>$ Chibar $^{2}$ & $\alpha$ & Result \\
\hline NPF & 0.0002 & 0.05 & $\left(\right.$ Prob $^{2}$ Chibar $\left.^{2}\right)<\alpha$ \\
\hline
\end{tabular}

Source: Processed secoundary data, 2020

Based on the Chow Test (Prob $>$ Chibar2) $<\alpha$ so that $\mathrm{H} 0$ is rejected, which means that the fixed effect model is more appropriate.

\section{Hausman Test}

The Chow test found that the random effect is more appropriate to use than pooled OLS and the LM test results that the fixed effect model is more appropriate to use than pooled OLS. Furthermore, the Hausman test is carried out to determine which model is more suitable between the random effect and the fixed effect. The null hypothesis $(\mathrm{H} 0)$ of the Hausman test is that the random effect model is more appropriate than the fixed effect model. If Prob $>$ Chi2 is less than $\alpha$ then $\mathrm{H} 0$ is rejected.

Table 3. Hausman Test Results

\begin{tabular}{cccc}
\hline Variable & Prob $>\mathrm{Chi}^{2}$ & $\alpha$ & Result \\
\hline NPF & 0.7793 & 0.05 & $\left(\right.$ Prob $\left.>\mathrm{Chi}^{2}\right)<\alpha$ \\
\hline Source: Procssed
\end{tabular}

Source: Processed secondary data, 2020

Based on the Hausman test (Prob $>$ Chi2) $>\alpha$ so that $\mathrm{H} 0$ is accepted, which means that the random effect model is more suitable than the fixed effect model.

\section{Conclusion of Test Results}

Based on the three tests that have been carried out in table 4, it is found that the most appropriate model to use is the random effects model.

Table 4. Regression Model Test Result

\begin{tabular}{cc}
\hline Type of Test & Result \\
\hline LM Test & Random effect \\
Chow Test & Fixed effect \\
Hausman Test & Random effect \\
\hline
\end{tabular}

\section{Classic assumption test}

The regression model used in this study is the random effect model so that the heteroscedasticity test and correlation test do not need to be conducted in the classical assumption test. 


\section{Normality test}

The purpose of the normality test is to investigate whether the data is normally distributed or not. Skewness/kurtosis was chosen as the method for doing the normality test.

Table 5. Normality Test Results

\begin{tabular}{lccccc}
\hline Variable & Obs & $\operatorname{Pr}($ Skewness) & $\operatorname{Pr}$ (Kurtosis) & Adj. chi ${ }^{2}(2)$ & Prob $>$ Chi $^{2}$ \\
\hline residual & 126 & 0.0014 & 0.0009 & 17.03 & 0.0002 \\
\hline
\end{tabular}

Source: Processed secondary data, 2020

Table 5 shows that the value Prob> chi2 is 0.0002 , which means less than 0.05 . This indicates that the data are not normally distributed. The assumptions of this test cannot be fulfilled one of the reason is that the sample size is quite large $(>30)$, which is 126 samples.

\section{Multicollinearity Test}

The purpose of multicollinearity testing is to see if there is a relationship between independent variables. The results of this test are shown in Table 6 , where the overall mean value is 1.75 . Meanwhile, the value of each independent variable is less than 10 which indicates that there is no multicollinearity problem in the research model used.

Table 6. Multicollinearity Test Results

\begin{tabular}{c|cc}
\hline Variable & VIF & 1/VIF \\
\hline ROA & 2.76 & 0.362573 \\
ROE & 2.39 & 0.419235 \\
BOPO & 1.42 & 0.703845 \\
FDR & 1.20 & 0.83314 \\
CAR & 1.01 & 0.989737 \\
\hline \multicolumn{2}{l}{ Mean VIF } & 1.75 \\
\hline \multicolumn{3}{l}{ Source: Processed secondary data, 2020 }
\end{tabular}

\section{Hypothesis Test}

The hypothesis test chosen in this study is the random effect regression model.

Table 7. Hypothesis Test Results

\begin{tabular}{lllll}
\hline \multicolumn{1}{c}{ Variable } & \multicolumn{1}{c}{ Coefficient } & Error Standard & t-statistic & p-value \\
\hline ROA & $-1.323257^{* * *}$ & 0.2908813 & -4.55 & 0.000 \\
ROE & 0.0145329 & 0.0312457 & 0.47 & 0.642 \\
FDR & -0.038537 & 0.0305811 & -1.26 & 0.208 \\
CAR & -0.031359 & 0.0447262 & -0.70 & 0.483 \\
BOPO & $0.0922608^{* *}$ & 0.0302402 & 3.05 & 0.002 \\
Constant & 0.0976367 & 0.0326416 & 2.99 & 0.003 \\
Observation & 126 & & & \\
R-squared & 0.4830 & & \\
Wald chi2 & 108.00 & & \\
Prob>chi2 & 0.0000 & & \\
Explanation: * significant on 0,05; **significant on 0,01; *** significant on 0,001 \\
Source: Processed secondary data, 2020
\end{tabular}

The probability value (Prob $>$ chi2) of table 7 on the F test is 0.0000 . The probability value on the $\mathrm{F}$ test is smaller than $\alpha(0.05)$ which indicates the model a whole is statistically signifant fits. Meanwhile, the R-squared value in the F test is 0.4830 which indicates that the 
independent variables ROA, ROE, FDR, CAR, and BOPO can explain the dependent variable NPF by $48.3 \%$.

The $t$ test indicates that in the dependent variable NPF, there are several independent variables that have a significant effect on NPF. These variables include Return on Assets (ROA) and Operating Expenses Operating Income (BOPO) with a significance level of 0.001 and 0.01 . The variables Return on Equity (ROE), Financing to Deposit Ratio (FDR), and Capital Adequacy Ratio (CAR) have no significant effect on NPF.

\section{Discussion}

\section{Return on Assets (ROA)}

The p-value of the ROA variable in table 7 is known to be 0.000 , which has a negative coefficient which indicates that ROA has a negative effect on NPF and has a significant effect at the 0.001 level of significance. This shows that when ROA decreases, it affects the increase in NPF. This finding is in line with research by Rahman et al. (2017) which analyzes 20 banks in the 2010-2015 period stating that NPL growth will slow interest income capacity because interest is not recognized and NPL provisions increase interest tension but reduce realized profits.

In addition, Ekanayake and Azeez (2015) found that banks with high profitability will have less pressure to be able to create income so that there are fewer obstacles in engaging in risky credit offers. This finding is also in line with the research of Dimitrios et al. (2016) which mentions ROA is a reflection of manager's efficiency in turning assets owned into profits so banks with high profitability tend not to take part in unsafe activities.

However, these findings are not in line with the research of Koju et al. (2018) who found that ROA had a positive effect on NPF.

\section{Return on Equity (ROE)}

Table 7 shows that the ROE variable has a p-value of 0.642 with a positive coefficient. This indicates that the ROE variable does not have a significant effect on problem financing (NPF) so that it does not support the research hypothesis. This finding is in line with the research of Vatansever and Hepsen (2013) which found that there was no significant effect of the ROE variable on NPL in a determinant study that affected the NPL ratio in Turkey from January 2007 to March 2013.

However, these results are not in line with the findings of previous studies by Kumar et al. (2018), Dimitrios et al. (2016), and Abid et al. (2014) which states that there is a negative impact of ROE on NPL which has a significant effect.

\section{Financing to Deposit Ratio (FDR)}

Based on table 7 , the $\mathrm{p}$-value of the FDR variable is 0.208 with a negative coefficient. This indicates that there is no significant effect on the dependent variable NPF so that it does not support the research hypothesis. This insignificant result is consistent with the findings of Gezu (2014) and Makri et al. (2014).

On the other hand, this finding contradicts Rahman et al. (2017) which describes the negative effect of FDR on NPL and has a significant effect with Sinkey and Greenwalt, 1991 in Rahman et al., 2017 further suggesting that rapid credit expansion may not be a problem by itself but can lead to poor screening and loans to lower quality borrowers.

\section{Capital Adequacy Ratio (CAR)}

The CAR variable has a p-value of 0.483 and has a negative coefficient which indicates that there is no significant effect on the NPF dependent variable so it does not support the research hypothesis. This finding is consistent with previous studies which state that the presence of large 
NPLs will have an impact on reducing the profit margins of many banks (Mukherjee, 2003 in Rahman et al., 2017). The insignificant effect of CAR on NPLs is in line with the results of research by Louzis (2012). On the other hand, these results are not in line with research Kumar et al. (2018) which states that CAR has a positive and significant impact on NPL.

\section{Operating Expenses Operating Income (BOPO)}

The $\mathrm{p}$-value of the BOPO variable in table 7 is known to be 0.002 with a positive coefficient which shows that BOPO has a positive effect on NPF and has a significant effect at the 0.01 significance level. These findings support previous research conducted by Koju et al. (2017) who argued that an increase in operating expenses increases inefficiency and inefficiency will in turn increase NPL. Furthermore, the positive influence of inefficiency on NPLs has led to poor management of the banking system which can lead to a banking crisis.

The results of this study are consistent with the research of Abid et al. (2014) on 16 Tunisian banks from 2003-2012 where there was a positive effect of BOPO on NPL. These findings suggest that Tunisian banks provide poor quality credit and do not use sophisticated evaluation methods to detect bankrupt creditors in advance.

Meanwhile, this study is not in line with the findings of Kumar et al. (2018) because it states that BOPO has a negative effect on NPL.

\section{Implication}

This research adds empirical evidence in the financial sector, especially banking risks related to the effect of financial performance on non-performing financing (NPF) of BPRS in DIY. Based on the authors' research findings, the ROA and BOPO variables have a significant effect on NPF with negative and positive coefficients, respectively.

The results of this study describe the influence of financial ratios (ROA and BOPO) on non-performing financing. This can encourage banking management to optimize other ratios that are presumed to affect NPF in order to suppress the increase in BPRS non-performing financing in DIY.

\section{Conclusion}

Based on the test results and discussion described, it can be concluded that ROA and BOPO have a significant effect on BPRS NPF in DIY. Meanwhile, ROE, FDR, and CAR do not have a significant effect on NPF.

This research is limited to the data used in the study only comes from published report data from the Financial Services Authority, the observation period is too short, the research is only conducted in BPRS DIY province, and the variables used are limited to ROA, ROE, FDR, $\mathrm{CAR}$, and BOPO.

Recommendations for further research are that research data beside coming from the OJK website can also be matched with annual reports published on the websites of each bank, the observation period is extended so that changes can be seen over a long period of time, the focus of research is carried out with a wider area coverage, for example in BPRS in other provinces or even throughout Indonesia, and subsequent research may add macroeconomic variables and other bank characteristic variables that are presumed to have an effect on NPF.

\section{References}

Abid, L., Ouertani, M. N., \& Zouari-Ghorbel, S. (2014). Macroeconomic and Bank-Specific Determinants of Household's Non-Performing Loans in Tunisia: a Dynamic Panel Data. Procedia Economics and Finance, 58-68. Retrieved from: https://www.sciencedirect.com/science/article/pii/S2212567114004304 
Alandejani, M., \& Asutay, M. (2017). Nonperforming loans in the GCC banking sectors: Does the Islamic finance matter? Research in International Business and Finance, 832-854. Retrieved from: https://www.sciencedirect.com/science/article/pii/S027553191630112X

Al-Wesabi, H., \& Ahmad, N. (2013). Credit risk of Islamic banks in GCC countries. International Journal Banking Finance, 1-18. Retrieved from: https://www.semanticscholar.org/paper/Credit-Risk-in-Islamic-Banks-of-GCCCountries-Al-Wesabi/b769a6baddb92111e9e130e90995fbcf13ffe808

Antonio, M. S. (2001). Bank Syariah dari Teori ke Praktik. Jakarta: Gema Insani.

Basuki, A. T. (2016). Pengantar Ekoonometrika (Dilengkapi dengan Eviews). Yogyakarta: Danis Media.

Dimitrios, A., Helen, L., \& Mike, T. (2016). Determinants of non-performing loans: Evidence from Euro-area countries. Finance Research Letters, 116-119. Retrieved from: https://www.sciencedirect.com/science/article/pii/S1544612316300538

Ekanayake E.M.N.N, A. A. (2015). DETERMINANTS OF NON-PERFORMING LOANS IN LICENSED COMMERCIAL BANKS: EVIDENCE FROM SRI LANKA. Asian Economic and Financial Review, 868-882. Retrieved from: https://www.emerald.com/insight/content/doi/10.1108/AJAR-10-2019-0080/full/html

Gezu, G. (2014). Determinants of NonPerforming Loans: Empirical Study in Case of Commercial Banks in Ethiopia. Jimma: Jimma University. Retrieved from: https:// core.ac.uk/download/pdf/30266984.pdf

Godlewski, C. J. (2004). Capital regulation and credit risk taking: Empirical evidence from banks in emerging market economics. Economics Working Paper Archive at WUSTL, 127-146. Retrieved from: https://www.ssrn.com/abstract $=588163$

Indrajaya. (2019). Determinan Non-Performing Financing pada Bank Umum Syariah di Indonesia. Jurnal Ekonomi dan Bismis Islam, 68-79. DOI: http://dx.doi.org/10.20473/jebis.v5i1

Jimenez, G., \& Saurina, J. (2006). Credit Cycles, Credit Risk, and Prudential Regulation. International Journal of Central Banking, 65-98. Retrieved from: https://www.ijcb.org/journal/ijcb06q2a3.htm

Koju, L., Koju, R., \& Wang, S. (2018, 3). Macroeconomic and Bank-Spesific Determinant of Non-Performing Loans: Evidence from Nepalese Banking System. Journal of Central Banking Theory and Practice, 111-138. Retrieved from: https://www.emerald.com/insight/content/doi/10.1108/AJAR-10-2019-0080/full/html

Kumar, R. R., Stauvermann, P. J., Patel, A., \& Prasad, S. S. (2018). Determinants of nonperforming loans in banking sector in small developing island states A study of Fiji. Accounting Research Journal, 192-213. Retrieved from: https://www.emerald.com/insight/content/doi/10.1108/ARJ-06-2015-0077/full/html

Kuncoro, M., \& Suhardjono. (2012). Manajemen Perbankan Teori dan Aplikasi. Yogyakarta: BPFE.

Louzis, D. P., Vouldis, A. T., \& Metaxas, V. L. (2012). Macroeconomics and bank-specific determinants of non-performing loans in Greece: A comparative study of mortgage, business and consumer loan portofolio. Journal of Banking \& Finance, 1012-1027. Retrieved from: https://www.sciencedirect.com/science/article/pii/S0378426611002895

Makri, V., Tsagkanos, A., \& Bellas, A. (2013). Determinants of Non-Performing Loans: The Case of Eurozone. PANOECONOMICUS, 2, 193-206. Retrieved from: https://core.ac.uk/download/pdf/25934815.pdf 
Mentari.news. (2019, April 3). 1,7 Juta UMKM Bangkrut, Tak Kuat Bersaing di Era 4.0. Retrieved Maret 23, 2020, from https://mentari.news/2019/04/17-juta-umkm-bangkrut-tak-kuatbersaing-di-era- 4.0

OtoritasJasaKeuangan. (n.d.). Apa itu Kredit dan Pembiayaan. Retrieved April 4, 2020, from https://sikapiuangmu.ojk.go.id/FrontEnd/CMS/Article/316

OtoritasJasaKeuangan. (2017). Informasi Umum Lembaga Kenangan Mikro. Retrieved Maret 21, 2020, from https://www.ojk.go.id/id/kanal/Pages/Lembaga-Keuangan-Mikro.aspx

Rahman, M. A., Asaduzzaman, M., \& Hossin, M. S. (2017). Impact of Financial Ratios on NonPerforming Loans of Publicly Traded Commercial Banks in Bangladesh. International Journal of Financial Research, 181-188. Retrieved from: https://www.semanticscholar.org/paper/Impact-of-Financial-Ratios-on-NonPerforming-Loans-Rahman-

Asaduzzaman/8bb7d8503e13fe0c4e096cba1de7a599e3ac1b9c

Vatansever, M., \& Hepsen, A. (2013). Determining Impacts on Non-Performing Loan Ratios in Turkey. Joumal of Finance and Investment Analysis, vol 2, no, 4, 119-129. Retrieved from: http://www.scienpress.com/Upload/JFIA\%2FVol\%202_4_7.pdf 